\title{
INFLUENCE OF MARITIME ADMINISTRATION ON THE DEVELOPMENT OF THE LNG MARKET
}

\section{ВПЛИВ МОРСЬКОГО АДМІНІСТРУВАННЯ НА РОЗВИТОК РИНКУ ЗРІДЖЕНОГО ПРИРОДНОГО ГАЗУ}

\begin{abstract}
The article analyzes the economic situation that has developed on the global market for liquefied natural gas. The administration in merchant shipping is worried about the situation associated with air pollution, as a result of which it imposes restrictions on the emissions of harmful substances for ships. It gives impetus to the development of the LNG market as a bunker fuel. The development of the economic potential of the global LNG market is based on the tightening of marine administration measures in relation to emissions of harmful substances into the atmosphere due to the operation of the fleet. In view of the general trends in the development of global shipping, shipowners are implementing alternative approaches to choosing the type of fuel. The key drivers of changes in market dynamics in the global LNG market are identified. The market of liquefied natural gas is considered, its current trends are identified. Demand in regional LNG markets is compared, features are analyzed, zonal demand and key players are highlighted, development prospects are advanced.

Key words: LNG market, maritime administration, global transport industry, global warming, shipping safety.
\end{abstract}

В статье анализируется экономическая ситуация, которая сложилась в глобальном рынке сжиженного природного газа. Администрирование в торговом судоход- стве обеспокоено ситуацией, связанной с загрязнением атмоссеры, вследствие чего вводятся ограничения на выбросы вредных веществ для судов, что и дает толчок для развития рынка сжиженного природного газа в качестве бункерного топлива. Развития экономического потенциала глобального рынка сжиженного природного газа основывается на ужесточении мер морского администрирования в отношении выбросов вредных веществ в атмосфреру вследствие эксплуатации фрлота. Ввиду общих тенденций развития глобального судоходства, судовладельцы реализуют альтернатив ные подходы к выбору типа топлива. Определены ключевые разрушительные силы изменений рыночной динамики в глобальном рынке сжиженного природного газа. Рассматривается рынок сжиженного природного газа, идентифрицированы его современные тенденции. Сравнивается спрос на региональных рынках сжиженного природного газа, анализируются особенности, выделяется зональный спрос и ключевые игроки, выдвигаются перспективы развития.

Ключевые слова: рынок сжиженного природного газа, морское администрирование, глобальная транспортная отрасль, глобальное потепление, безопасность судоходства.

У статmі аналізується економічна ситуації, яка склалася на глобальному ринку зрідженого природного газу. Адміністрування в торговельному судноплавстві стурбоване ситуацією, пов'язаною із забрудненням атмосфери, внаслідок чого вводяться обмеження на викиди шкідливих речовин для суден, що і дає поштовх для розвитку ринку зрідженого природного газу в якості бункерного палива. 3 огляду на загальних тенденцій розвитку глобального судноплавства, судновласники реалізують альтернативні підходи до вибору типу палива. Це все відкриває унікальне вікно можливостей для зрідженого природного газу, який більш привабливий за своїми екологічними параметрами, не кажучи вже про економіку питання. Розглядаються найважливіші умови і фрактори фформування основних параметрів глобального ринку зрідженого природного газу. Увага акцентується на закономірностях збалансованості функціонування даного сектору морської транспортної індустрії. Виділяються аспекти інноваційних та мультимодальних транспортних технологій. Визначаються пріоритети національних і регіональних програм досягнення екологічної та транспортної безпеки. Враховуються напрями і найважливіші завдання спеціалізації в системі конкурентного позиціонування транспорту окремих країн і судноплавних підприємств. Визначено ключові рушійні сили зміни ринкової динаміки на глобальному ринку зрідженого природного газу. Розглядається ринок зрідженого природного газу, ідентисріковані його сучасні тенденції. Порівнюється попит на регіональних ринках зрідженого природного газу, аналізуються особливості, виділяється зональний попит і ключові гравиі, висуваються перспективи розвитку. Проаналізовано використання зрідженого природного газу в якості палива водним транспортом з позиції оцінки ефективності роботи суднової рухової установки і забезпечення екологічної безпеки. Питання переведення суднової енергетики на газ принципово вирішене, проте необхідно відпрацювати технологію бункерування суден зрідженим природним газом і його зберігання на борту (в першу чергу для суден, які не є газовозами). У статті узагальнено наявний міжнародний досвід в цьому напрямку і дана оцінка перспективи розвитку суден бункерувальників і берегових бункерувальних терміналів.

Ключові слова: Ринок зрідженого природного газу, морське адміністрування, глобальна транспортна галузь, глобальне потепління, безпека судноплавства.

Problem statement. The problem of climate warming on Earth has become global and one of the pressing environmental problems of our time. There are many causes of this planetary phenomenon, but most of them are directly caused by human activity.

Gas is much more environmentally friendly than other fossil fuels, i.e. coal and oil, which is of great importance for the maritime administration in struggling against air pollution in shipping.

Since 2000, export-import of liquefied natural gas has more than doubled on the planet, primarily due to demand in Asia. Today, LNG accounts are for $40 \%$ of the physical volumes of world gas trade; by 2040, its share will increase to $60 \%$ (reducing the role of pipeline gas to 40\%). In 2018 alone, China increased the import of liquefied natural gas by $40 \%$, and global demand for it in the near future, by the end of 2020 , will grow by $20 \%$ [9].

There had been observed the natural-gas market growth at its fastest rate in almost a decade last year, supported by booming domestic markets in China and the United States and an expanding global gas trade to serve Asian markets. While the pace of growth is set to slow, gas remains the fastest-growing 
fossil fuel and the only fossil fuel expected to grow beyond 2035 [4].

The production level of liquefied natural gas on the territory of Ukraine in 2018 amounted to 396.5 thousand tons (3.5\% less than in 2017). According to the results of 2018, there were 114 companies importing liquefied natural gas in Ukraine. The largest importer was the Nadezhda group of companies, which produced 137.7 thousand tons of fuel, followed by the BRSM-Nafta gas station network with a rate of 132.4 thousand tons, and Karpatnaftochim, which purchased 103.1 thousand tons of LNG [5].

Liquefied natural gas is rapidly changing the face of the global gas industry. Whereas in the 20th century, blue fuel was exported mainly through pipes, in the 21st century it is increasingly delivered in tankers. For Ukraine, this means opportunities and risks: forming and developing its own fleet, it increases the level of security of the country, stimulating competition for pipelines.

Literature review. The study of the LNG market development devoted to the outlooks [3-10] that assess the global market for liquefied natural gas and highlights key trends from 2018 as well as future supply and demand.

Research objective. The purpose of the study is to generalize the principles and parameters of the integrated use of liquefied natural gas as bunker fuel and, accordingly, the parameters of the global LNG market.

Key results. The losses from global warming exceed many times the total budgets of many developed countries. Climatic disasters are becoming increasingly burdensome for the global economy. In 2018 in the United States alone, as a result of natural disasters, budget damage amounted to $\$ 91$ billion. According to the United Nations, global warming could damage the world economy by $\$ 1.45$ trillion by the end of the century.

Due to global warming, which is the cause of these anomalies, the world's largest corporations see climate change as a threat that will amount to more than $\$ 1$ trillion of damage to their business. Modern entrepreneurs are forced to take into account the damage from the global warming when drawing up a development strategy, adapting their infrastructure to a changing world.

In May 2019, the instruments of the famous Mauna Loa Observatory registered a record value of the average concentration of carbon dioxide in the atmosphere, which amounted to 414.7 ppm. According to Science Daily, this figure has been increasing for seven years, which is associated with an increase in anthropogenic emissions.

The administration of merchant shipping is carried out through the implementation of standards and regulations of international and national institutional organizations. The international maritime administration system is focused on shipping safety. It is funda- mental in the administration of merchant shipping to achieve the legitimacy of the activities of shipowners and operators.

The main goal of administration is to minimize the negative consequences of the functional activities of the fleet and ports in the real world development of the global transport industry [2].

Merchant shipping administration is concerned about air pollution. In view of this, restrictions on emissions of harmful substances for water transport are introduced, which in turn provides an impetus for the development of the LNG market as a bunker fuel.

In connection with this situation, the requirements of the International Maritime Organization (IMO) have been tightened with respect to the quality parameters of marine fuel permitted in zones of the North, Baltic Seas and the English Channel. From January 1, 2015 , the sulfur content in the fuel should not exceed $0.1 \%$, which led to the exclusion of further use of marine fuel oil and gas oil. In August 2012, the same quality parameters were introduced in the coastal 200-mile zone of North America.

Shipowners are forced to switch to environmentally friendly fuel, i.e. an alternative to fuel oil used. LNG is more attractive in terms of its environmental and economic parameters: 1.5-2 times cheaper than gas oil and fuel oil.

New restrictions on vessel engine emissions in the world pose a challenge for shipowners:

1. The use of low-sulfur gas oil, fuel oil, diesel, which will lead to an increase in processing costs and significantly increase the cost of low-sulfur fuel;

2 . The installation of scrubbers and a selective catalytic reduction system (SCR) for the appropriate purification of exhaust gases from sulfur and nitrogen dioxide, which capital and operating costs are very high;

3. The use of LNG as marine fuel.

In 2018, according to the Center for Strategic and International Studies (which specializes in energy and national security and is based in Washington) there were 6 largest gas producers in the world, share of which accounted for more than $60 \%$ of global gas exports: Qatar, the USA, Russia, Australia, Norway and Canada. But the last three have limited shortterm growth potential for gas supplies and provide mainly one region: Asia, Europe or North America. In turn, Qatar, the USA and Russia have big plans for expanding capacities and can supply LNG to several regions at once.

The rapid development of the LNG market began in the 1990s. This market is more similar to the world oil market than to the traditional trading in pipeline gas, which is exported only to the main gas pipelines, the length of which usually does not exceed 4000 kilometers. In turn, in 2017, the average route of the LNG gas carrier amounted to 15.5 thousand kilometers.

Thus, the possibility of liquefied gas deliveries by sea radically changes the development trends of the 
global gas industry. As a result, large exporters of the industry, namely countries that are far from major markets in Asia and Europe (Australia, Nigeria) and / or because of their island nature (Indonesia, Trinidad and Tobago), could not become pipeline gas suppliers, are exporting LNG now, using the increasingly numerous and large LNG gas carriers. As a result, supply grows and competition intensifies sharply.

In view of the growing demand in particular for LNG in Asia, since 2000, export-import of liquefied natural gas has more than doubled on the planet. Today, LNG accounts for $40 \%$ of global gas trade; by 2040 , its share will increase to $60 \%$, which will reduce the role of pipeline gas to $40 \%$. In 2018, China increased the import of liquefied natural gas by $40 \%$, and global demand for it in the near future, by the end of 2020 , will increase by $20 \%$.

In 2018, 18 countries produce and export LNG. In 2017, its supplies amounted to 323 billion cubic meters or 230 million tons [9]. Qatar is the world leader in the LNG market. Until recently, Australia, which is not particularly positioning on the global gas market, ranks second in the list of countries with LNG production capacities (Fig.1). Malaysia, Indonesia, Algeria, and Nigeria also have large liquefaction capacities.

Japan is the world's largest LNG receiver. The group of world leaders in LNG reception (Fig. 2) also includes China, which led the list of the largest importers in 2018. In Europe, Spain is the largest importer of LNG and the owner of the largest number of receiving terminals, geographically located farther than others from traditional pipeline gas suppliers: Russia, Norway and the Netherlands. There are 7 Spanish terminals in the Atlantic Ocean and the Mediterranean Sea.

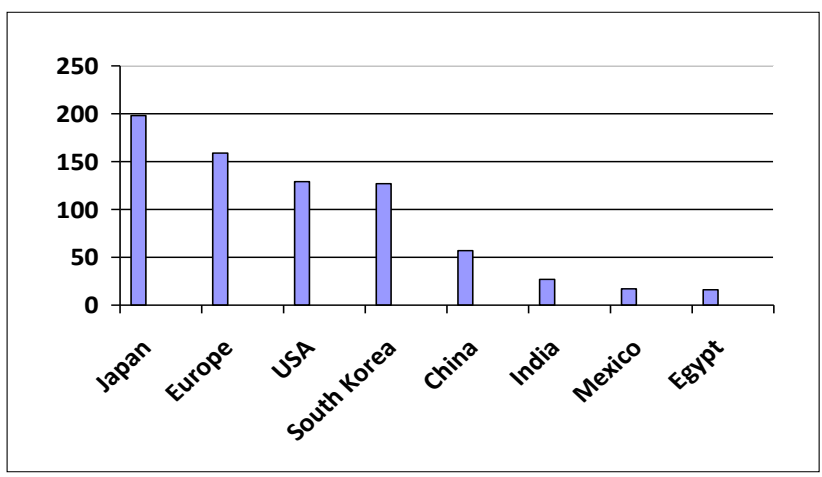

Fig. 2. LNG regasification capacities in 2018 , in million tons

Source: Shell interpretation of IHS Markit, Wood Mackenzie, FGE and Poten \& Partners Q4 2018

In 2018, Japan had the largest capacity for regasification of liquefied natural gas, but many of the facilities were unloaded due to lower demand [10]. Europe running second, if we consider all the EU countries and Turkey. In the USA, such terminals are mostly idle, and China uses its capacity in full.

Currently, there are about 120 LNG receiving terminals on the planet in 42 countries. The total capacity of existing terminals exceeds 850 million tons, which is twice as much as global gas liquefaction capacities. Receiving terminals are sometimes built not only for purely economic reasons, but also because of the desire to gain independence from suppliers.

In 2018, China, overtaking Japan, became the world's largest importer of LNG. Beijing is rapidly replacing coal in the power industry with greener gas to reduce air pollution in major cities in China.

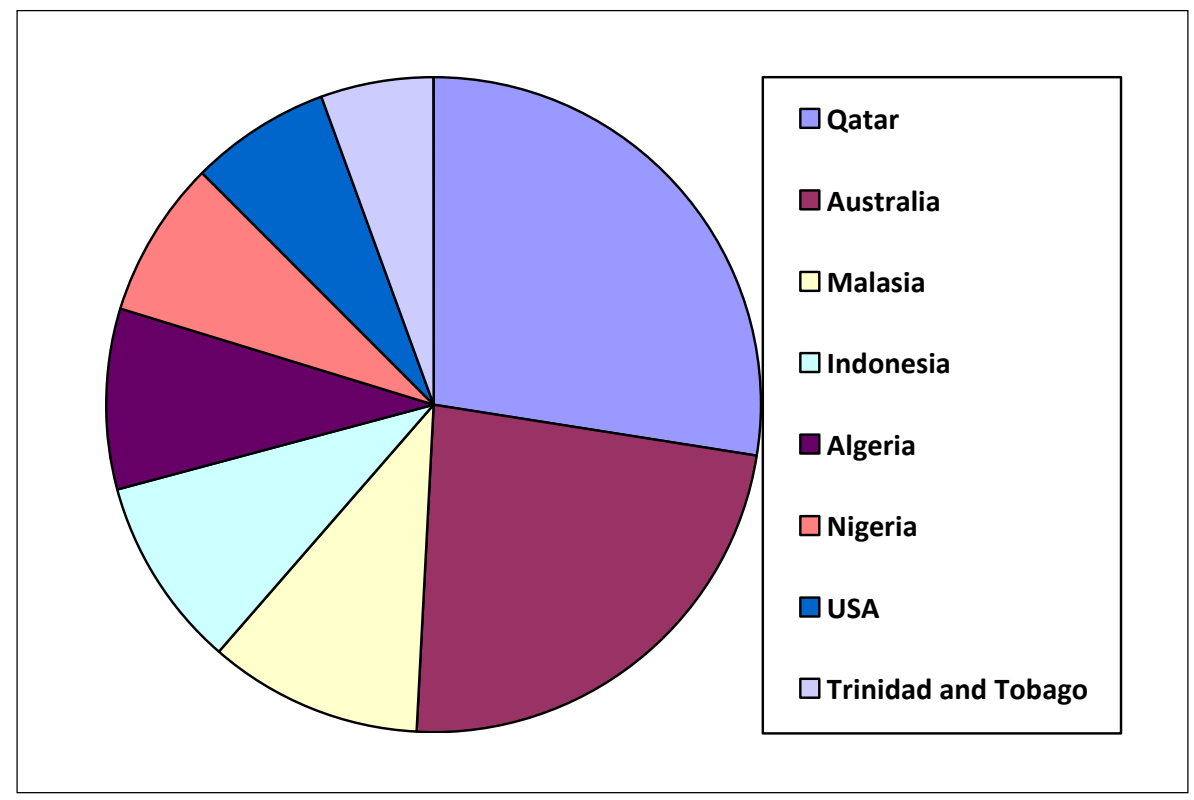

Fig. 1. LNG production capacities in 2018 , million tons 
LNG terminals can be not only stationary, but also mobile. The world's largest floating gas liquefaction plant, Prelude, was launched in 2018 about 500 kilometers west of Australia. And in Lithuania, in the port of Klaipeda, since 2014 the Independence regasification vessel has been operating, which accepts LNG, in particular, from Norway and the USA.

LNG regasification is optional, i.e. it can also be used in liquid form as motor fuel, it is much cleaner than diesel and fuel oil. Shell predicts that by 2040, 6,000 vessels will use liquefied natural gas due to tightening emissions standards from the maritime administration and requirements from environmentally-friendly passenger liners. In 2018, Germany built the first cruise ship operating exclusively on LNG: AIDAnova.

LNG refueling can also be floating. Since the beginning of 2019, the world's largest bunkering vessel with LNG Kairos, the Hamburg company Nauticor, began to operate in the Baltic and the North Sea. Its main task is to carry out operational refueling of all kinds of watercraft off the northwestern coast of Europe, which have already switched to the most environmentally friendly marine fuel.

Conclusions. In the twentieth century, scientists tried to solve the problem of global warming through the development and implementation of a number of engineering innovations and transport and organizational and technical measures related mainly to methods of suppressing heat and gas emissions. Powerful anthropogenic or artificial sources of atmospheric pollution by flue gases are virtually all heat engines and power plants that burn hydrocarbon fuels. Together with the exhaust and exhaust gases, about 60-90 percent of the total heat energy produced by combustion is discharged, which leads to thermal pollution of the atmosphere.

Maritime administration's success in making the air cleaner shows the critical role of the LNG market. It images into providing more and cleaner energy to around the world. Strong demand for cleaner-burning fuel in Asia continued to drive rapid growth in liquefied natural gas (LNG) use in 2018, with global demand rising by 27 million tons to 319 million tons.

\section{REFERENCES:}

1. Kostylev I. I., Ovsyannikov M. K. (2009) Morskaya transportirovka szhizhennogo gaza [Sea transportation of liquefied gas]. Sankt Peterburg: GMA im. Makarova.

2. Frasinyuk T. I. (2012) Faktory i zadachi morskogo administrirovaniya $v$ razvitii ukrainskogo torgovogo flota [Factors and tasks of maritime administration in the development of the Ukrainian merchant fleet]. Visnyk ekonomiky transportu i promyslovosti: zb. nauk.-prakt. statei. Kharkiv: UDAZT. vol. 39, pp. 76-79.

3. LNG Market Trends and Their Implications/International Energy Agency and Korea Energy Economics Institute. - France: IEA and KEEI, 2019. 82 p.

4. Global gas and LNG outlook to 2035/September 2019 McKinsey Insights. - Available at: https://www.mckinsey.com/industries/oil-and-gas/ourinsights/global-gas-and-Ing-outlook-to-2035 (accessed 29 November 2019).

5. Global Project Task Force (GPTF) Second Meeting / Global Ballast Water Management Programme: Proceedings (IMO Headquarters, London, 6-8 December, 2000). London: IMO, 2002. 78 p.

6. BLEENS - Biogas, Liquefied Petroleum Gas, Electricity, Ethanol, Natural Gas, and Solar. Available at: https://energypedia.info/wiki/BLEENS_-_Biogas,_Liquefied_Petroleum_Gas,_Electricity,_Ethāonol,_Natural_ Gas,_and_Solar (accessed 29 November 2019).

7. EU's Natural Gas Price Statistics (2019). Available at: https://ec.europa.eu/eurostat/statistics-explained/ pdfscache/45229.pdf (accessed 29 November 2019).

8. PTT: Natural Gas Information. Available at: https:// www.pttplc.com/en/media-center/energyknowledge/ documents/gas_en1.pdf (accessed 29 November 2019).

9. IEA's Outlook for Natural Gas (2018). Available at: https://www.iea.org/publications/freepublications/publication/WEO2017Excerpt_Outlook_for_Natural_Gas.pdf (accessed 29 November 2019).

10. SHELL LNG OUTLOOK 2019. Available at: https://www.international-bc-online.org/wp-content/ uploads/2019/06/2_20190528-OB-IBC-on-LNG-Outlook_Eng.pdf (accessed 29 November 2019).

11. Frasyniuk T., Primachev N., Importance of administration and entepreneurship in the development of Ukrainian sea transport. Contemporary Economy Electronic Scientific Journal "Współczesna Gospodarka". 2013. Vol. 4. Issue 2. p. 25 - 32. Available at: http://www.wspolczesnagospodarka.pl (accessed 29 November 2019). 
Frasyniuk Tatyana

Candidate of Economic Sciences, Associate Professor,

Senior Lecturer at Department of Economic Theory and Entrepreneurship in Maritime Transport

National University

"Odessa Maritime Academy"

\section{INFLUENCE OF MARITIME ADMINISTRATION ON THE DEVELOPMENT OF THE LNG MARKET}

The article discusses the principles and parameters of integrated use of liquefied natural gas as a bunker fuel. In the twentieth century, scientists tried to solve the problem of global warming through the development and implementation of a number of engineering innovations and transport, organizational and technical measures related mainly to methods of suppressing heat and gas emissions. Powerful anthropogenic or artificial sources of atmospheric pollution by flue gases are virtually all heat engines and power plants that burn hydrocarbon fuels. Together with exhaust gases, about 60-90 percent of the total heat energy produced by combustion is discharged, which leads to of the atmosphere.

Due to global warming, which is the cause of these anomalies, the world's largest corporations see climate change as a threat that will amount to more than $\$ 1$ trillion of damage to their business. Modern entrepreneurs are forced to take into account the damage from global warming when drawing up a development strategy, adapting their infrastructure to a changing world.

The administration of merchant shipping is carried out through the implementation of standards and regulations of international and national institutional organizations. The international maritime administration system is focused on shipping safety. It is fundamental in the administration of merchant shipping to achieve the legitimacy of the activities of shipowners and operators.

In connection with this situation, the requirements of the International Maritime Organization (IMO) have been tightened with respect to the quality parameters of marine fuel permitted in the zones of the North, Baltic Seas and the English Channel. From January 1, 2015, the sulfur content in the fuel should not exceed 0.1\%, which led to the exclusion of further use of marine fuel oil and gas oil. In August 2012, the same quality parameters were introduced in the coastal 200-mile zone of North America.

Shipowners are forced to switch to environmentally friendly fuel, i.e. an alternative to fuel oil used. LNG is more attractive in terms of its environmental and economic parameters: 1.5-2 times cheaper than gas oil and fuel oil.

New restrictions on vessel engine emissions in the world pose a challenge for shipowners:

1. The use of low-sulfur gas oil, fuel oil, diesel, which will lead to an increase in processing costs and significantly increase the cost of low-sulfur fuel;

2. The installation of scrubbers and a selective catalytic reduction system (SCR) for the appropriate purification of exhaust gases from sulfur and nitrogen dioxide, the capital and operating costs of which are very high;

3. The use of LNG as marine fuel.

Liquefied natural gas is rapidly changing the face of the global gas industry. Whereas in the 20th century, blue fuel was exported mainly through pipes, in the 21st century it is increasingly delivered in tankers. For Ukraine, this means opportunities and risks: forming and developing its own fleet, it increases the level of security of the country, stimulating competition for pipelines. 